\title{
New insights on the migration of monarch butterflies in North America: a focused collection of studies
}

https://doi.org/10.1515/ami-2018-0009

Edited by Andrew K. Davis, with help from guest-editor, Keith Hobson

There has never been a more important time for research focusing on the migration of the monarch butterfly in North America. There have been well-publicized declines in overwintering colonies of both the eastern and western North American populations, and a growing body of evidence points to the importance of the migration as one of the primary causes for these declines [1-3]. It is now apparent that the journey to reach the overwintering grounds is just as important, if not more, than is the conditions or resources available during the breeding season.

This collection of papers represents an important step toward improving scientific understanding of the monarch migration, and in pinpointing the perils and challenges faced by migrating monarchs. The articles published in this collection have been authored by leading experts on the biology of monarchs and their migration, and these papers not only demonstrate the latest topics that are being explored by these scientists, but also showcase a variety of methodological advances now being employed to study monarchs. These include isotopic analyses of wing tissue, computer-based image analyses of wing morphology, assays of cardenolide content in tissues, and even tensile strength measurement of monarch wings! A brief synopsis of these articles is below, although it is by no means exhaustive.

The first article includes perhaps some of most fascinating findings of the collection. Freedman and Dingle examined current and archived specimens of monarchs, dating back to the $19^{\text {th }}$ century to explore changes in wing morphology across time and between regions of North

*Corresponding author: Andrew K. Davis, Odum School of Ecology, University of Georgia, Athens GA 30602, E-mail: akdavis@uga.edu
America. By using digital image analyses to examine fine-scale features of monarch wing morphology, they determined that monarchs in North America have gradually increased in size (and are continuing to increase) over the last 100 years. They present evidence that this could be due to a shift in the type of milkweed available on the landscape, but it is also possible that this size increase reflects the increasingly perilous migration; the migration acts to remove small-winged monarchs each year. In support of this, the authors show that overwintering monarchs tend to be larger than are nonoverwintering ones, and even that eastern overwintering monarchs are larger than those at western overwintering sites, reflecting the much greater distance (and selective force) of the eastern journey.

Long-term declines of monarchs at the eastern overwintering sites, but the absence of similar declines in counts of breeding or migrating monarchs [3-5], has led to much speculation about what is happening to monarchs during the journey to Mexico. One possibility that has been little-explored is the idea that monarchs may be gradually shifting their migratory course away from Mexico, travelling elsewhere to overwinter. The study by Vander Zanden et al. is suggestive of this possibility. These authors examined wing tissue of monarchs collected during winter in south Florida, using a stableisotope approach to elucidate where they originated from. Surprisingly, half of the monarchs tested appeared to come from the Midwestern United States! This implies that Mexico is not the final destination of ALL migrating monarchs in the eastern population. While these results are based on a small sample size, the evidence leads one to question old assumptions about the migratory journey.

Migrating while infected with parasites would be challenging for any species, and monarchs are no exception. Monarchs are prone to a debilitating protozoan parasite, Ophryocystis elektroscirrha (OE), which is known to cause reductions in migration success $[6,7]$. With this in mind, Davis and de Roode investigated one potential, but 
unexplored, mechanism for this migration failure, which is that infections reduce wing tissue growth and make them more prone to damage. They found that OE-infected monarchs tended to have thinner, lighter, wings, presumably because the infection impaired optimal wing tissue growth during metamorphosis. Then, using a force meter, they determined that wings of infected monarchs were more easily torn or damaged. Wing damage incurred during the two-month migration, even minor tears, would be severely incapacitating and likely lead to migration failure [8]. Given that millions of infected monarchs begin the migration each fall $[6,9]$, these findings help to determine why so few of these monarchs reach their winter destination.

Monarchs, like all flying migrants, must contend with adverse weather during their journey. Climate change means that hurricanes are becoming increasingly prevalent during the fall $[10,11]$, coinciding with the time when monarchs are travelling. Ries and colleagues contributed a paper that explores the potential consequences and effects (both direct and indirect) of hurricanes on monarchs and also birds. While much of their essay is literature review and/or theoretical, their conclusions point to the idea that hurricane pose more of a problem for monarchs after the fact, when the inundated landscape grows lush, often with non-native or out-ofseason vegetation, including tropical milkweed.

Monarch migration is a two-way journey, although the journey north from Mexico differs greatly from the southbound trip, since northbound monarchs are primarily concerned with ovipositing, and since the entire northward journey spans multiple generations. Surprisingly little is known about the physical characteristics of spring migrants compared to those in the fall. That is one of the reasons the article by Ruiz Vargas et al is significant; these authors examined monarchs at a single site in Michigan during spring, summer and fall, looking at fat loads, egg counts, and wing loading. Their results show how spring females have high wing loading compared to summer monarchs because of the weight of eggs. Wing loads increase as the fall departure nears, reflecting the buildup of fat reserves for the journey. In fact, in the monarchs they sampled prior to migration, as much as $25 \%$ of their weight was lipids. Early research conducted by the late Lincoln Brower demonstrated how this fat is used as both fuel for the migration and also sustains the monarchs during the winter months, and the monarchs need to have close to $50 \%$ fat loads by the time they reach Texas [12].
Finally, the passing of Dr. Brower earlier this year, who was a champion of monarch conservation, was felt by all who study and appreciate monarchs. His scientific legacy is a wealth of literature, data and science on this insect, which is even now being expanded upon, as indicated above. While his death has left a void in the research world, especially on issues related to the monarch migration, it is heartening to see that many researchers, such as those featured in this collection, are continuing in his footsteps. On behalf of the authors of these articles, I am honored to dedicate this collection to Lincoln's memory.

\section{References}

[1] Agrawal A.A., Inamine H., Mechanisms behind the monarch's decline, Science, 2018, 360(6395), 1294-6

[2] Badgett G., Davis A.K., Population trends of monarchs at a northern monitoring site: analyses of 19 years of fall migration counts at Peninsula Point, MI, Annals of the Entomological Society of America, 2015, 108(5), 700-6

[3] Inamine H., Ellner S.P., Springer J.P., Agrawal A.A., Linking the continental migratory cycle of the monarch butterfly to understand its population decline, Oikos, 2016, 125(8), 1081-91

[4] Davis A.K., Are migratory monarchs really declining in eastern North America? Examining evidence from two fall census programs, Insect Conservation and Diversity, 2012, 5(2), 101-5

[5] Ries L., Taron D.J., Rendon-Salinas E., The disconnect between summer and winter monarch trends for the eastern migratory population: possible links to differing drivers, Annals of the Entomological Society of America, 2015, 108(5), 691-9

[6] Bartel R.A., Oberhauser K.S., de Roode J.C., Altizer S.M., Monarch butterfly migration and parasite transmission in eastern North America, Ecology, 2011, 92(2), 342-51

[7] Bradley C.A., Altizer S., Parasites hinder monarch butterfly flight: implications for disease spread in migratory hosts, Ecology Letters, 2005, 8, 290-300

[8] McCord J.W., Davis A.K., Characteristics of monarch butterflies (Danaus plexippus) that stopover at a site in coastal South Carolina during fall migration, Journal of Research on the Lepidoptera, 2012, 45, 1-8

[9] Flockhart D.T.T., Dabydeen A., Satterfield D.A., Hobson K.A., Wassenaar L.I., Norris D.R., Patterns of parasitism in monarch butterflies during the breeding season in eastern North America, Ecological Entomology, 2018, 43(1), 28-36

[10] Trenberth K.E., Cheng L.J., Jacobs P., Zhang Y.X., Fasullo J., Hurricane Harvey links to ocean heat content and climate change adaptation, Earths Future, 2018, 6(5), 730-44

[11] Hurricanes and climate change. Collins JM, Walsh K, editors. Switzerland: Springer International Publishing; 2017.

[12] Brower L.P. New perspectives on the migration biology of the monarch butterfly, Danaus plexippus, L. In: Rankin MA, editor. Migration: mechanisms and adaptive significance. 27 (Supplement). Austin, TX: Univ. Texas Contrib. Marine Sci.; 1985. p. 748-85. 